\title{
Academic stress levels in university students caused by the application of alternative assessment methods in English language learning.
}

Niveles de estrés académico en estudiantes universitarios causados por la aplicación de métodos de evaluación alternativos en el aprendizaje del idioma inglés.

Romero Villarroel Wilber Orlando. ${ }^{1}$, Camacho Estrada Sara Nidhya. ${ }^{2} \&$ Valencia Núñez Edison Roberto. ${ }^{3}$

\begin{abstract}
.
The different evaluation methods and approaches existing in the field of higher education generally provoke various psycho-behavioral reactions in university students. The objective of this work is to analyze the relationship between the application of alternative assessment in the field of language learning and the level of stress generated before during and after those assessments. The SISCO inventory of academic stress was applied to two hundred and nineteen students. Additionally, the Alpha Cronbach, and Friedman's nonparametric statistical tests were used to process the data collected. Consequently, the research was qualitative and quantitative. The results indicated that students experience a higher level of stress when starting an evaluation, marked as peak when applying alternative assessments with an "of learning" assessment approach that measures only knowledge acquired, while in assessments with a "for learning" and "as a means of learning"- type approach, the results show a standard trend in the moments, before, during, and after the assessment. Thus, it is concluded that the most assertive way to decrease the stress levels experienced by students is by applying assessments as a means of learning.
\end{abstract}

\footnotetext{
${ }^{1}$ Universidad Técnica de Ambato, Ambato, Ecuador, wo.romero.@uta.edu.ec

${ }^{2}$ Universidad Técnica de Ambato, Ambato, Ecuador, scamacho.@uta.edu.ec

${ }^{3}$ Universidad Técnica de Ambato, Ambato, Ecuador, edisonrvalencia.@uta.edu.ec
} 
Keywords: Alternative assessment, assessment approaches, academic stress, psychometric tests.

\section{Resumen.}

Los diferentes métodos y enfoques de valuación existentes en el ámbito de la enseñanza a nivel superior, generalmente provocan diversas reacciones de tipo psico-conductual en estudiantes universitarios. El objetivo de este trabajo es analizar la relación entre la aplicación de métodos de evaluación alternativa en el campo del aprendizaje de idiomas y el nivel de estrés generado antes durante y después de dichas evaluaciones. Se aplicó el inventario SISCO del estrés académico a doscientos diecinueve estudiantes. Además, los test no paramétricos de Alpha Cronbach y Friedman fueron usados para procesar los datos recolectados. Por consiguiente, la investigación fue de tipo cualitativa y cuantitativa . Los resultados indicaron que los estudiantes experimentan un nivel más alto de estrés al iniciar una evaluación, marcada como pico cuando se aplican evaluaciones alternativas con un enfoque de evaluación "de aprendizajes" la cual mide únicamente conocimientos adquiridos, mientras que en evaluaciones con un enfoque de tipo "para aprendizajes" y "como medio de aprendizajes, los resultados muestran una tendencia estándar en los momentos, antes, durante y después de la evaluación. Es así que se concluye que la forma más asertiva de disminuir los niveles de estrés que experimentan los estudiantes es mediante la aplicación de evaluaciones como medio de aprendizaje.

Palabras claves: Evaluación alternativa, enfoques de evaluación, estrés académico, tests psicométricos

\section{Introduction.}

There is a wide variety of ways to assess students' learning language progress. Depending on the objectives and process applied, it can result in high, low, or null stress levels in students. Thus, this study focuses on how alternative assessment increases or reduces stress depending on the method and approaches applied. This study uses the term alternative assessment, which is also known as authentic, integrated or holistic because it focuses on the process as reported by Tsagari (2011). What students can or cannot do in contrast to what they do or do not do rather than in the product, marks the difference with the process applied in evaluation which focuses more in the product according to Shavelson (2013). It is fundamental to have a clear idea about testing, evaluation and assessment, thus Pereira, D.et al (2016) in the first case, says testing covers the measurement of the level of skill or knowledge. In the second situation, evaluation is a process of making judgments based on defined criteria. In the last case, assessment involves documenting knowledge, skills, and abilities in measurable terms and then applying methods to improve upon them. 
Alternative assessment as a method and tool according to Stufflebeam, D. et al (2000) has been used in many educational fields to value in some cases and in others to score skills, abilities and knowledge. It is defined as a system which follows a cyclical repetitive process. It starts on planning, using the plan, revising the students' outcomes and feeding them back based on results

The evolution of authentic assessment consists on many necessary changes to understand what, when, and how students learn as it was supported by Brown and Pickford (2013); Casanova, (2012); and Sanmarti, (2007). Therefore, assessment becomes an influential tool in the teaching area to guide students on what and how responses must be given on specific evaluations, a position supported by Gibbs (2003). Furthermore, important aspects such as different approaches in "assisted assessment, self-assessment" (Sanmarti, 2007), "pair assessment" (López, 2012), and "group assessment"; as well as methods related to "essays, portfolios, quizzes, tests, among others" (Brown and Pickford, 2013) are the bases in a general assessed process. It is important to mention that assessment as well as learning aren't linear and both can take many directions based on progress and objectives reached.

Depending on the type of task and tool used to assess students, they affect their stress level and results. In order to mention options that are applied in this assessing system, it could be said that portfolios, tests, self-assessment, pair assessment, group assessment are the most common ones used in class. One of the most used assessing activities is group assessment. It is understood as a group activity where working as a team with peers on common tasks provide ways of thinking strategies, mutual construction feedback and appreciation for the value of cooperative and collaborative learning process, besides helping to attain knowledge of difficult or complex skills. The application of different assessment activities, like the one mentioned, provoke on students their continuously reorganization and revision of their internal conceptions of the world, which are called "mental codes", "knowledge structures", or "schema" according to Herman, J. et all (1992). In reference to the way alternative assessment rules its results process, it is known that in most cases it needs scoring criteria, a scoring guideline, rubrics, and scoring rubrics. Criteria constitutes an important characteristic in this assessing system because they help to judge complex human performance in a reliable, fair, and valid manner in which an assessment is applied. Furthermore, when having the results, it is discussed with students which help to internalize in order to make them independent learners. All of this process is important because equitable and meaningful scores require informed and consisted judgment.

In reference to the approaches applied when assessing students, it is a relevant part because of the students' reactions when applying them. This study focuses on three important lines of assessing "of learning", "for learning", and "as a means of learning". According to the first approach, it is designed specifically to inform about knowledge, or provide data that 
helps to check what a student can or can't do. In the second line, assessment for learning is focused mostly on what can be done in response to the students' results. It is oriented to the learning process rather than on outcomes. The last approach is centered on students' autonomous development, where they tend to look for their own goals, challenges and constant problem solving to learn a concept supported by Eccles, J.S., \& Wigfield (2002). Indeed, assessment becomes a tool for learning instead of a passing or failing grade.

Assessment can become an ally or an enemy for students depending on what, how, when, who, where among other factors it is applied. The stress levels that assessment provoke is a determining factor for their achievement. Most of them have experienced anxiety before, during and after a test. The feeling of worry, fear, nervousness and dread influence negatively on their performance. Thus, the results on a test, depending on the level of anxiety, can meaningfully reduce their average, which is the cause of the $32 \%$ of student' dropouts according to the American Health Association, 2006. This reduction in the results has consequences on students' self-esteem, motivation, and confidence. Some external conditions that make students feel under pressure when having a test are: timing, intimidation, lack of preparedness, unclear instructions, and poor previous results. On the other hand, there are other internal factors that could affect student' performance such as: student' nervousness, fear of letting down others, focusing too much on single tests, lack of motivation and self-esteem, feeling with no control, fear of poor grades, family problems, economic problems, and so on. Furthermore, students might face physical symptoms like racing heartbeat, nausea, stomachaches, headaches, shaking chills, etc. depending on the person according to Arslan, (2017). As it can be seen, stress is a serious situation that affects students on their psychological and physical aspects.

These effects come from internal or external experiences as it was mentioned before. Zhang, (2016), claims that long terms stress causes cognitive, emotional and behavioral problems. Consequently, students who have high level expectations of themselves tend to put a lot of pressure on the results they want to get which causes lack of ability to deal with mistakes or can easily feel dumbfounded. In the same way, students who are not prepared for a test, have to deal with stressful moments as well. It mainly happens due to putting off studying, not understanding the subject, lack of organization, or procrastination. In any case case, students suffer mind freezing or go mentally black during a test. It is called a disappointment about academic failure and mental distress which is characterized by fear of being unsuccessful according to Verma and Gupta (1990).

A very effective system that has been applied to identify and measure stress levels of students is the SISCO inventory of academic stress. It is a reliable and validated tool that has been used by researchers. It is a questionnaire designed from interrelated variables, namely selfperceived stress levels, stressors and symptoms - coping. This questionnaire has 31 items 
divided into six sections: 1.- It is a filter to identify whether the chosen students have the same characteristics. 2.- It allows to identify the level of self-perceived stress. 3.- It deals with the information about the stressors. 4-6.- It is about symptoms and strategies applied by students to cope with stress. This inventory was proposed and proved by García et al (2016).

\section{Methodology.}

The present study focuses on alternative assessment considering the following approaches: OF learning, FOR learning and AS A MEANS of learning. In the same way the recurrences of the test applied to measure the levels of stress students face ocurred: before, during and after a test. This process helps to analyze the different forms, moments and results in an assessment process according to Hernández (1998).

The participants for the present study were 219 students chosen randomly from different language levels and time schedules from the Languages Center at the Technical University of Ambato. The assessment and the SISCO inventory of academic stress was applied according to the following process:

Table. 1: Type, approach and recurrence of the assessment method.

\begin{tabular}{|c|c|c|c|c|}
\hline \multirow[b]{2}{*}{$\begin{array}{l}\text { TYPE OF } \\
\text { ASSESSMENT }\end{array}$} & \multirow[b]{2}{*}{ TEST APPROACHES } & \multicolumn{3}{|c|}{ RECURRENCE } \\
\hline & & BEFORE & DURING & AFTER \\
\hline & OF LEARNING & $x$ & $x$ & $x$ \\
\hline FORMATIVE - & FOR LEARNING & $x$ & $x$ & $x$ \\
\hline ALTERNATIVE & $\begin{array}{l}\text { AS A MEANS OF } \\
\text { LEARNING }\end{array}$ & $x$ & $x$ & $x$ \\
\hline
\end{tabular}

Made by: Research group

The SISCO questionnaire presents 31 items organized in three systemic-process parameters: 1) stressful stimuli (input), 2) symptoms (imbalance indicators) and 3) coping strategies (output). These components are determined in a quali - quantitative Likert scale from 1 to 5 , where 1 represents a little and five represents a lot. This questionnaire was applied before, during and after each type of evaluation with its respective approach as shown in the table above.

The instruments with their corresponding evaluation approaches were applied on different dates in a coordinated manner allowing the student not to know the type of evaluation to which they would be subjected. The contents and implementation procedures were carefully planned by the research group in such a way they would coincide in dates and in the possible topics to be evaluated. Thus, the results would not be biased. 
The procedure included informing the student about the test to be taken and, right BEFORE starting, the student would complete the 1st SISCO questionnaire. Then, DURING the development of the test, the student would be required to complete the 2nd SISCO questionnaire and finally AFTER completing the assessment, the student would again be asked to complete the 3rd SISCO questionnaire. This process was applied for collecting data of the thee assessing approaches: OF learning, FOR learning, AS a means of learning.

After collecting the entire data, the tabulation of the information was done. For this both the Alpha Cronbach, and Friedman's nonparametric statistical tests were used, generating reliable quantitative results for the corresponding interpretation. A correlative and qualitative interpretation of the data determined the stress levels and affectations depending on the type and assessment approach used in the tests.

\section{Results.}

\section{Assessment OF Learning}

For the analysis of reliability of the survey, the Cronbach's Alpha statistical procedure was applied. This procedure resulted in a 0,953 value which shows that the survey holds a high reliability level.

The Friedman's nonparametric statistical test was run in order to measure the level of stress generated before, during and after the assessment. This test showed a 0,000 p-value which indicates that there are significant differences in the three moments of test applications, proving the BEFORE parameter to be the one with the greatest level of stress as it shows a median of 4 on a $0-5$ scale.

Table 2: Stress level statistics found in assessment tests with an OF learning approach.

\begin{tabular}{llll}
\hline Statistical Processing & & & \\
\hline & Before & During & After \\
Population & 219 & 219 & 219 \\
Mean & 3,38 & 3,01 & 2,49 \\
Median & 4,00 & 3,00 & 3,00 \\
\hline
\end{tabular}

Made by : Reseach group

The descriptive mean and median statistical procedures were applied in order to determine the type of questions which generated the highest level of nervousness in students in the moment of taking a test. The results are as follows: 
Table 3: Stressors and strategies to cope with stress in assessment tests with an OF learning approach

\begin{tabular}{lll}
\hline STRESSORS & Recurrence & Median \\
\hline $\begin{array}{l}\text { Ignoring the type of assessment applied by } \\
\text { the teacher }\end{array}$ & Before & 4 \\
$\begin{array}{l}\text { Expectation about the test content. } \\
\text { STRATEGIES TO COPE WITH STRESS }\end{array}$ & Before & 4 \\
$\begin{array}{l}\text { Assertive Skills (Acceptance of reality } \\
\text { Making of a mental plan to remember the } \\
\text { most important test contents. }\end{array}$ & $\begin{array}{l}\text { Before - after } \\
\text { Before - after }\end{array}$ & 3 \\
\hline
\end{tabular}

Made by : Reseach group

According to these results, questions related to not knowing the type of test the students will be confronted to, as well as ignoring the content being tested generates the highest stress BEFORE taking the test. On the other hand, students turn to accepting their reality and making mental plans to remember important content as strategies to lessen their stress levels BEFORE and AFTER taking the test.

\section{Assessment FOR Learning}

Again, for the analysis of reliability of the survey, the Cronbach's Alpha statistical procedure was applied. This time the analysis resulted in a 0,968 value which shows that the survey displays a high reliability level.

The Friedman's nonparametric statistical test was run in order to measure the level of stress generated before, during and after the assessment test. This test showed a 0,000 p-value which indicates that there are significant differences in the three moments of test applications. The median statistical test is applied in order to see the highest level of nervousness on a 0 5 scale.

Table 4: Stress level statistics found in assessment tests with a FOR learning approach.

\begin{tabular}{llll}
\hline Statistical Processing & & & \\
\hline & Beforer & During & After \\
Population & 219 & 219 & 219 \\
Mean & 3,38 & 3 & 2,49 \\
Median & 3,00 & 3,00 & 3,00 \\
\hline
\end{tabular}

Made by: Research group

The table shows that there is a high level of stress right before taking the assessment whilst during the test the level of stress remains in a lower level. However, after the test, the stress becomes moderate. 
In the same way, the descriptive mean and median statistical procedures were applied in order to determine the type of questions which generated the highest level of nervousness in students while taking a test. The most representative questions are detailed in the following table:

Table 5: Stressors and strategies to cope with stress in assessments with a FOR learning approach

\begin{tabular}{lll}
\hline STRESSORS & Recurrence & Median \\
\hline $\begin{array}{l}\text { Ignoring the type of assessment } \\
\text { applied by the teacher }\end{array}$ & Before - during & 3 \\
$\begin{array}{l}\text { Expectation about the test content. } \\
\text { STRATEGIES TO COPE WITH STRESS }\end{array}$ & Before & 3 \\
\hline $\begin{array}{l}\text { Assertive Skills (Acceptance of reality } \\
\text { Making of a mental plan to remember } \\
\text { the most important test contents. }\end{array}$ & Before - after & 3 \\
\hline
\end{tabular}

Made by: Research group

According to this table, in this type of assessment, not knowing the type of test the students will be confronted to, generates stress BEFORE and DURING the test. Also having expectations about what is going to be tested generates stress Before the test. Similarly, students turn to accepting their reality and making mental plans to remember important content as strategies to decrease their stress levels BEFORE and AFTER taking the test.

\section{Assessment AS A MEANS of Learning}

For the survey reliability analysis, the Cronbach's Alpha statistical procedure was also used. The value was 0,97 which denoted a high reliability level. In order to determine the level of stress in the three different moments of test application, the Friedman's nonparametric statistical test was also applied. The p-value also resulted in 0,000 which means there are important differences of results before, during and after the test taking. Finally, in order to identify the highest stress level on a $0-5$ scale, the mean and median statistical test is applied.

Table 6: Stress level statistics found in assessment tests with an AS A MEANS OF learning approach.

\begin{tabular}{lrrr}
\hline Statistical Processing & \multicolumn{3}{l}{} \\
\hline & Before & During & \multicolumn{1}{c}{ After } \\
Population & 219 & 219 & 219 \\
Mean & 2,92 & 2,47 & 2,04 \\
Median & 3,00 & 3,00 & 2,00 \\
\hline
\end{tabular}

Made by : Reseach group 
It is clearly seen that the stress level is mostly present BEFORE the assessment test represented in a 2,92 median. Very interestingly, during the assessment test, the stress levels decreased importantly and after the test it even reached lower level.

With the aim of identifying the stressors in this type of assessment, a descriptive mean and median statistical procedures were applied which identified the following questions and strategies to cope with stress.

Table 7: Stressors and strategies to cope with stress in assessments with an AS A MEANS OF learning approach

\begin{tabular}{lll}
\hline STRESSORS & Recurrence & Median \\
\hline $\begin{array}{l}\text { Ignoring the type of assessment applied by } \\
\text { the teacher }\end{array}$ & Before & 3 \\
$\begin{array}{l}\text { Expectation about the test content. } \\
\text { STRATEGIES TO COPE WITH STRESS }\end{array}$ & Before & 3 \\
\hline $\begin{array}{l}\text { Assertive Skills (Acceptance of reality) } \\
\begin{array}{l}\text { Making of a mental plan to remember the } \\
\text { most important test contents. }\end{array}\end{array}$ & $\begin{array}{l}\text { Before- after } \\
\text { Before- after }\end{array}$ & 3 \\
\hline
\end{tabular}

Made by: Research group

Once Again, it is noticeable that "Ignoring the assessment type employed by the teacher and having expectations of the test content" provoke important levels of stress BEFORE the test application. Students tend to constantly use assertive skills and mental plans as strategies to cope with anxiety during the different times of a test.

\section{Conclusions.}

- The type of assessment that cause the most stress in students corresponds to Formative Assessment with an "OF learning" approach. There is a high level of nervousness BEFORE and DURING the application of this type of assessment. The characteristic components of this type of evaluation increase anxiety since its approach is primarily aimed at obtaining a score which allows a student to be promoted or not. Students do not know on "what" or the "How" they are going to be tested and so, in order to minimize their stress, they turn to strategies such as acceptance of their reality and try to remember important content before and after the assessment.

- Very interestingly, assessments with a "FOR learning" approach also denote high levels of stress before and during their applications. This is because this type of evaluation presents more specific characteristic of execution. Furthermore, it also focuses on what the student knows and can do with regard to a topic. When not 
knowing on what and how students are going to be tested, stress levels before and during the test increase. However, once this is discovered, their levels of stress decrease as the students are clear about the test type and its content they are subjected to.

- Conversely, in assessments with an "AS A MEANS of learning" approach, stress levels are different. It is possible to demonstrate that at all times of the test application, students do not denote relevant psycho-behavioral reactions. This is probably mainly because this type of assessment does not consider the use of any scoring method as evidence of learning. Rather, its focus goes further into the metacognitive field of learning. Metacognition calls for self-reflection and self-regulation processes as an autonomous means of learning

- In general, it is observed that the implementation of any assessment process with a metacognitive and language awareness approach, decreases stress levels. However, this does not mean that through this approach of assessment learning is optimal compared to the first two approaches. If any interest arises around this topic, then it would become very preeminent to investigate which aspects from each of the assessment approaches mentioned above, are the determinants to promote meaningful learning and that at the same time significantly decrease stress levels when taking tests.

\section{Bibliographic References}

Arslan, N. (2017). Investigating the Relationship between Educational Stress and Emotional Self-Efficacy. Universal Journal of Educational Research. Sitio web: https://files.eric.ed.gov/fulltext/EJ1155536.pdf_(Viewed: November 2019).

Brown, S. \& Pickford. R., (2013). Evaluación de habilidades y competencias en educación superior. Narcea.

Casanova, M., (2012). El diseño curricular como factor de calidad educativa. Revista Iberoamericana sobre Calidad, Eficacia y Cambio en Educación, vol. 10, núm. 4, pp. 7-20, on: http://www.rinace.net/reice/numeros/arts/vol10num4/art1.pdf (Viewed: october 2019).

Eccles, J.S., \& Wigfield, A. (2002). Motivational beliefs, values and goals. Annual Review of Psychology.

Gibbs, Grahan (2003). Uso estratégico de la evaluación en el aprendizaje. Evaluar en la universidad: problemas y nuevos enfoques.

García, S. et al (2016). Identification and Classification of Academic Stress by Galvanic Skin Response. Visión Electrónica.

Hernan, J. et all (1992). A Practical guide to alternative assessment. Office of Educational 
Research and Improvement.

López, V., (2012). Evaluación formativa y compartida en la universidad: clarificación de conceptos y propuestas de intervención desde la Red Interuniversitaria de evaluación Formativa. Psychology, Society, \& Education, vol. 4, núm. 1, pp. 117-130, on: http://www.psye.org/articulos.php?id=86 (viewed: september 2019).

Pereira, D., Assunção, M. \& Niklasson, L. (2016) Assessment and Evaluation in Higher Education, , 41:7, 1008-1032, DOI: 10.1080/02602938.2015.1055233.

Sanmartí, N., (2007). 10 ideas clave: evaluar para aprender.

Shavelson, R., (2013). Modeling and Measuring Competencies in Higher Education. An Approach to testing \& Modeling Competence.

Stufflebeam, D. L., Madaus, G. F., \& Kellaghan, T. (2000). Evaluation models, (Rev. ed.).

Tsagari, D., (2011). Language testing and evaluation. Classroom based language assessment.

Verma, S. \& Grupta. J. (1990). Some aspects of high academic stress and symptoms. Journal of Personality and Clinical Studies.

Zhang, L. et al (2016). Long-term academic stress enhances early processing of facial expressions. International Journal of Psychophysiology.

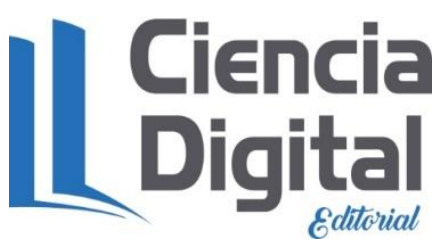




\section{Para citar el artículo indexado.}

Wilber Orlando, R. V., Sara Nidhya, C. E., \& Edison Roberto, V. N. (2020). Academic stress levels in university students caused by the application of alternative assessment methods in English language learning. Explorador Digital, 4(2), 22-33. https://doi.org/10.33262/exploradordigital.v4i2.1198

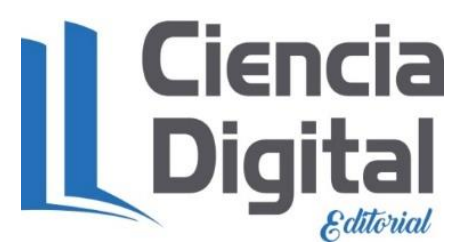

El artículo que se publica es de exclusiva responsabilidad de los autores y no necesariamente reflejan el pensamiento de la Revista Explorador Digital.

El articulo queda en propiedad de la revista y, por tanto, su publicación parcial y/o total en otro medio tiene que ser autorizado por el director o editor de la Revista Explorador

Digital.
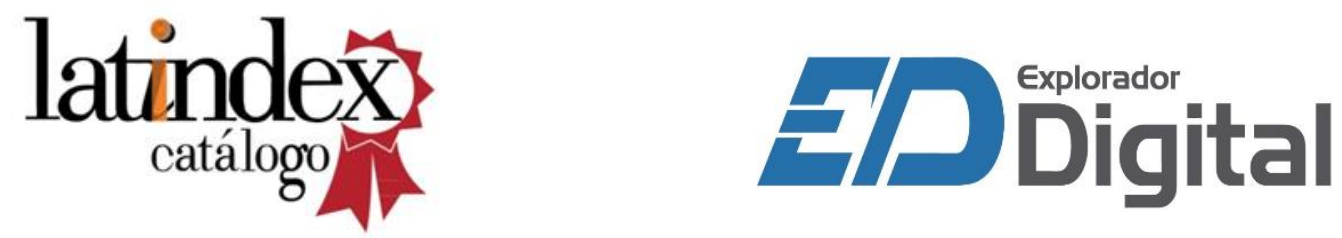